\title{
Drop of efficiency of herbicide Citadel 25 OD m.d. in sowings of rice
}

\author{
T. Dudchenko, Candidate of Agricultural Sciences \\ L. Tsilynko, I. Falkovskyi \\ Institute of rice NAAS
}

The purpose. To determine the causes of drop of efficiency of herbicide Citadel $25 \mathrm{OD}$ m.d. in sowings of rice and to fix emersion of resistant populations of Japanese barnyard millet. Methods. Field small-plot experiments - regular registration of weeds according to procedure on the stationary plots on the 21th day and before harvesting. The gained experimental data were processed using method of analysis of variance. Results. In conditions of long use of herbicide Citadel 25 OD m.d. efficiency of the registered doses has dropped from 100 to $34,9 \%$. At use of the specimen without any system efficiency of the registered doses of $1,5 \mathrm{l} /$ hectare made $97-100 \%$. It testifies to the absence on the yielded plots of stable biotypes of Japanese barnyard millet, sensitive to this herbicide. Conclusions. As a result of long application of herbicide Citadel 25 OD m.d. on the basis of Penoxulam on paddies the population of Japanese barnyard millet insensitive to action of the specimen appeared.

Key words: rice, herbicides, resistance, weeds.

Since the appearance of agriculture the problem of protecting crops from weeds has arisen. With the development of the agricultural technology, the methods for the eradication, of the competitors of the cultivated plants, have been continuously improved. However, the adaptation of weeds to the existence in the cultural plant communities is so perfect that this problem has not still been solved even nowadays [1].

According to various authors, weeds can cause losses from $10 \%$ to $80 \%$ of a grain yield [2]. In the climate conditions of Ukraine more than 30 species of weeds occur on rice crops, but the most important influence on rice yield have the types of the barnyard millet (Echinochloa).

Echinochloa is an economically important genus of plants, many of which are very harmful for agriculture, particularly for the rice-growing (Holm et al., 1977). The utter environmental sustainability, including the ability to adapt to the cycle of rice, rapid growth and development, high seed production makes from this genus - one, very dangerous type of weeds (Mennan et al. +2014)

As a result of long and permanent usage of herbicides with the same mechanism of action, a decrease in the efficiency of drugs and the emergence of resistant biotypes of plants is marked. The stability or resistance to herbicide - is the ability of separate biotypes of an individual weed species to survive after treatment with the herbicide, the application of which, in normal conditions against this kind would lead to a complete destruction of the plants of this form [3,4]. It is known that weed resistant biotypes are always present in populations of the species - that is a part of the normal type of genetic variation. The permanent and repeated use of the same herbicide or herbicides with the same mechanism of action will lead to the selection of resistant biotypes that have resistance to this mechanism of action and/or strengthen mechanisms of the cleavage (degradation) of the herbicide. Certain biotypes of weeds can have both excellent chemical resistance to herbicides or to drugs with different mechanisms of action. In field conditions, when the same herbicide or herbicides of one chemical class are used constantly, herbicide resistance can develop after $4-5$ years $[5,6]$.

The number of new drug-resistant forms is always growing. The international data bank (International Survey of Herbicide-Resistant Weed) has information about 323 resistant biotypes, 187 species (112 dicots and 75 monocots) [7].

Today we have the problem of reducing the effectiveness of herbicides on crops of rice in general. One of the dominant herbicides used in rice production, $80 \%$ of this sowing is Citadel $25 \mathrm{ppm}$ OD (penoxsulam $25 \mathrm{~g} / \mathrm{l}$ ). This herbicide, like the most that are allowed to use on crops of rice in Ukraine by its 
mechanism of action belongs to ALS inhibitors (acetolactate synthase inhibitors). Long term and permanent use, in turn, led to the formation of stable populations of barnyard grass [8].

The purpose of research - to establish the reasons for reducing the effectiveness of the herbicide and to determine the appearance of resistant populations of barnyard grass in rice.

Research methods. The experiments and observations were carried out at the Institute of NAAS rice.

One of the methods defining resistance is the usage of the investigational drug in different conditions, namely in areas with long and systematic use and without systematic application.

Analysis has been made to study the efficiency of herbicide Citadel 25 OD on sectors with long-term (systematic) use for more than 4 years and without systematic application.

In the conducted experiment with the long usage of penoxulam the effectiveness of half recommended, one and half and triple of the norm of the drug against grass weeds was examined (table. 1.). The study was posted on the crop varieties Ontario, planted on the survey area where, in general, for the period from 2007 to 20145 treatments were held with the herbicide on the basis of penoxsulam (2008, 2009, 2010, 2012, 2013, 2014).

In the experiment without systematic application of penoxsulam the recommended rates of herbicide were studied. The experiment was laid on crops varieties Ontario, planted on the survey area where 3 herbicide treatments were carried out on the basis of penoxsulam $(2008,2009,2012)$

Experiments on small areas, (the space of which is approximately $100 \mathrm{~m}^{2}$ ), were repeated four times; the location of the sites was random counted. The data processing was performed according to the technical regulations of the herbicides application. The scheme of experiment involved 1 processing. The determination of the effectiveness was done at fixed sites with an area of $0.25 \mathrm{~m}^{2}$ for 21 days and before gathering.

Results of studies: The experimental plots had a high degree of contamination of $40-100 \mathrm{pc} . / \mathrm{M} 2$ barnyard grass plants. Sectors where penoxulam has been used for a long time had a maximum efficiency in versions with standard 2.0-2.5 $\mathrm{l} / \mathrm{ha}$ of herbicide, characterized by the fact that such high standards were not registered, but such a high efficiency of $100 \%$ was not persisted until the end of culture vegetation, repeated regrowth of barnyard grass was noticed. Increased rates up to $3.0 \mathrm{l} / \mathrm{ha}$ did not have the desired increase of the efficiency, but on the contrary - it indicated a decrease to $78 \%$. Application of the rules for the 1.0-1.5 $\mathrm{l} / \mathrm{ha}$ in these conditions had very low efficiency in the range $56 \%$ to 21 days and $25-34 \%$ before collection (Table 1 ).

\section{1 - Efficiency of the herbicide Citadel 25 OD, in the background of long-term use}

\begin{tabular}{|l|c|c|c|c|c|}
\hline \multirow{2}{*}{ A variant of the experience } & \multicolumn{2}{|c|}{ The number of barnyard millet, pieces $/ \mathrm{m}^{2}$} & \multicolumn{2}{|c|}{ Efficiency, \% } \\
\cline { 2 - 6 } & $\begin{array}{c}\text { before } \\
\text { processing }\end{array}$ & 21 days & $\begin{array}{c}\text { before } \\
\text { gathering }\end{array}$ & 21 days & $\begin{array}{c}\text { before } \\
\text { gathering }\end{array}$ \\
\hline $\begin{array}{l}\text { Control } \\
\text { (without treatment) }\end{array}$ & 78 & 83 & 86 & - & - \\
\hline Citadel 25 OD (1.0 I/ha) & 100 & 20 & 64 & 56,5 & 25,6 \\
\hline Citadel 25 OD (1.5 I/ha) & 90 & 20 & 56 & 56,5 & 34,9 \\
\hline Citadel 25 OD (2.0 I/ha) & 66 & 0 & 14 & 100 & 83,7 \\
\hline Citadel 25 OD (2.5 I/ha) & 88 & 0 & 0 & 100 & 100 \\
\hline Citadel 25 OD (3.0 I/ha) & 40 & 10 & 26 & 78,3 & 69,8 \\
\hline
\end{tabular}

Processing with low standards 1,0-1,5 I/ha did not cause complete eradication of weeds; but it was marked by yellowing of leaves, deformation (twisting) of individual leaves and shoots, the delay of the panicle output and its deformation. However, during the growing season plants have formed seeds.

On condition that treatments for the experimental plots were made without systematic application of penoxulam, a different pattern was observed. Even the low rates of herbicide had high effectiveness, 
which practically did not change until the harvest gathering, so the norm of $1.0-1.2 \mathrm{l} /$ ha 21 days was characterized by $100 \%$ effectiveness against grass weeds (table. 2 ).

\section{2 - Effectiveness of herbicide Citadel 25 OD, without systematic application}

\begin{tabular}{|l|c|c|c|c|c|}
\hline \multirow{2}{*}{ A variant of the experience } & \multicolumn{2}{|c|}{ The number of barnyard millet, pieces $/ \mathrm{m}^{2}$} & \multicolumn{2}{|c|}{ Efficiency,\% } \\
\cline { 2 - 6 } & $\begin{array}{c}\text { before } \\
\text { processing }\end{array}$ & 21 days & $\begin{array}{c}\text { before } \\
\text { gathering }\end{array}$ & 21 days & $\begin{array}{c}\text { before } \\
\text { gathering }\end{array}$ \\
\hline $\begin{array}{l}\text { Control } \\
\text { (without treatment) }\end{array}$ & 78 & 83 & 86 & - & - \\
\hline Citadel 25 OD (1.0 I/ha) & 100 & 20 & 64 & 56,5 & 25,6 \\
\hline Citadel 25 OD (1.2 I/ha) & 90 & 20 & 56 & 56,5 & 34,9 \\
\hline Citadel 25 OD (1.4 I/ha) & 66 & 0 & 14 & 100 & 83,7 \\
\hline Citadel 25 OD (1.5 I/ha) & 88 & 0 & 0 & 100 & 100 \\
\hline
\end{tabular}

Providing that the processing of barnyard grass was made according to the registered rules in conditions of no prolonged use, penoxulam efficiency remained at a high level of $95-100 \%$.

\section{Conclusions}

To sum up, the analysis of the conducted research indicates that the result of the use of herbicide Citadel $25 \mathrm{OD}$ on the basis of penoxsulam, on rice fields has formed the population of barnyard millet which is not sensitive to the action of the drug. Therefore the effectiveness of this herbicide was halved. With the long usage of herbicide at a rate of $1.5 \mathrm{l} /$ ha efficiency was $56.5 \%$ for 21 days and $34,9 \%$ before gathering. On areas where the herbicide was used fewer times at the rate of $1.5 \mathrm{l} / \mathrm{ha}$, we had the efficiency to 21 days of $97.6 \%$, before the harvest - $100 \%$. This high efficiency shows that plants of barnyard millet are sensitive to this herbicide.

\section{Bibliography}

1. E. Yu Murderer. The herbicides. Mechanisms of action and practice of usage /E. Yu Murderer., Yu, Mariinsky. - K.: Logo, 2009. - 379 P.

2. Agarkov C. D. Theory and practice of chemical crop protection feature/Agarkov C. D. Kasyanov A. I.//Krasnodar. - 2000. - $336 \mathrm{P}$.

3. Protermosolar/under the General editorship of Professors M. D. Evtushenko, F. M. Maruta. - K.: Higher education, 2004. - 432 S.

4. Storchous I. M., Resistance weed herbicide/l. M. Storchous//Protection and Plant Quarantine. 2011. - Edition. 57 - P. 188 -198.

5. Ivashchenko A. A., Green Neighbors/A. A. Ivashchenko. - K .: Phoenix, kolobih, 2013. - 480 p.

6. Methods of testing and use of pesticides/S. O. Triebel, D. D. Siharova, M. P. Sekun, A. A. Ivashchenko, etc .; edited by Prof.. S.O. Triebel - K .: Svit. - 2001. - P. 379-382.

7. Evolved resistance to glyphosate in rigid ryegrass (Lolium rigidum) in Australia/[Powles, S.B., Lorraine-Colwill, D.F., Dellow, J. F. \& Preston, C.]-1998/Weed Science 46.604-607.

8. Dudchenko V. V. Growing rice current issue and answers/V. V. Dudchenko, T. V. Dudchenko, O. M. Shevchuk//Zerno. - 2015. - №10 (115). - P.100-101.

9. Kondratiev A. The change of stability in the systematic use of oats fenoxaprop-P-ethyl/A. A. Kondratiev//Agricultural science - farmer economy, coll. Articles in 3 books./III Intern. Scientific-prac. Conf. - Barnaul: Publishing house ASAU, 2008. Book. 1. - P.316-318.

10. Perez A. Glyphosate-resistant Lolium multiflorum in Chilean orchards./Perez A, Kogan M. - 2003. Weed research, 43, 12-19. 